\title{
技術論文
}

\section{ブロモピロガロールレッドとニオブ $(\mathbf{V})$ を用いる製剤中 のマレイン酸クロルフェニラミンの吸光光度定量}

\author{
中川 幸代*，森 逸 男 ${ }^{*}$, 松尾 敬子*, 重村 康之*，藤田 芳一 ${ }^{\circledR *}$
}

\author{
Spectrophotometric determination of chlorpheniramine \\ maleate in pharmaceutical preparations \\ with Bromopyrogallol Red and niobium(V)
}

Sachiyo NAKagaWA, Itsuo Mori, Takako Matuo, Yasuyuki SHigemura and Yoshikazu FujITA*

\begin{abstract}
* Osaka University of Pharmaceutical Sciences, 4-20-1, Nasahara, Takatsuki-shi, Osaka 569-1024
(Recieved 4 June 1999, Accepted 17 July 1999)

A spectrophotometric method for the determination of chlorpheniramine maleate (CPM) was established by using Bromopyrogallol Red(BPR) and niobium(V). This method can be used to determine $2 \sim 32 \mu \mathrm{g} / 10 \mathrm{ml} \mathrm{CPM}$ at $635 \mathrm{~nm}$. The apparent molar absorptivity is $8.0 \times 10^{4} 1 \mathrm{~mol}^{-1} \mathrm{~cm}^{-1}$ with a relative standard deviation $(n=8$, $19.6 \mu \mathrm{g}$ ) of $0.83 \%$. The proposed method, which is a simple procedure without separation, was applied to assays of CPM in pharmaceutical preparations (eye drop, syrup, capsule and lotion). The analytical results and recoveries were satisfactory.
\end{abstract}

Keywords : chlorpheniramine maleate; spectrophotometry; pharmaceutical preparations; Bromopyrogallol Red and niobium(V).

\section{1 緒言}

著者らは，色素，金属イオン及び被分析物質（薬物） 間の三元錯体生成反応系を利用する薬物定量法が, 色 素-薬物あるいは金属イオンー薬物の二元錯体生成反応 系を用いた従来法に比べ, 感度, 選択性, 簡便性などの 種々の点で優れていることを認め, 本反応系を用いてこ れまで多くの薬物の実用分析法を報告した ${ }^{1)-5)}$. 今回は 抗ヒスタミン薬として複合製凨中に広範囲に含有されて いるマレイン酸クロルフェニラミン（CPM）に対し， 色素としてブロモピロガロールレッド（BPR），金属イ

\footnotetext{
* 大阪薬科大学: 596 - 1094 大阪府高柣市奈佐原 4- 20-1
}

オンにニオブ(V) $\{\mathrm{Nb}(\mathrm{V})\}$ を用いるとき $\mathrm{CPM}$ との発 色反応が鋭敏であり，既に報告した $o$-ヒドロキシヒド ロキノンフタレインーチタン (IV) -フッ化物 $\{\mathrm{QP}-\mathrm{Ti}$ (IV)-F $\mathrm{F}^{-}$法占に優ることを認めた. したがって, その最 適定量条件を設定し, 市販複合製剤 (点眼棛, シロップ 凨, カプセル剤, ローション郕) 中の CPM の分析に応 用したところ，良好な結果が得られたので報告する。

\section{2 実験}

\section{$2 \cdot 1$ 試薬及び装置}

$\mathrm{CPM}$ 溶液：シグマ製の CPM を水に溶解して $1.0 \times$ $10^{-4} \mathrm{M}$ 水溶液として用いた。

BPR 溶液：ヤンセン製の BPR を用い，メタノールに 
溶解して, $2.0 \times 10^{-3} \mathrm{M}$ を調製して用いた

$\mathrm{Nb}(\mathrm{V})$ 溶液: キシダ化学製の原子吸光用標準溶液 （1000 ppm）を適宜 $1.0 \times 10^{-3} \mathrm{M}$ 水溶液として用いた.

Tween 40 溶液: ナカライテスク製 Tween 40 を水に 溶解して $1.0 \%$ 水溶液として用いた.

緩衝液: Walpole の $0.2 \mathrm{M}$ 酢酸一酢酸ナトリウム緩衝 液を液性調整に用いた。

その他の試薬は，市販特級品をそのまま用いた。また 本実験では，イオン交換水，再蒸留メタノールを使用し た。

分光光度計：吸収スペクトル及び吸光度の測定に島津 製作所製 UV-160A 型分光光電光度計で層長 $10 \mathrm{~mm}$ の石 英製セルを用いた。

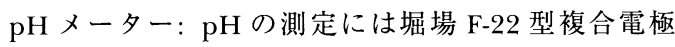

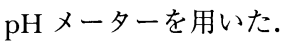

\section{$2 \cdot 2$ 定量操作}

$10 \mathrm{ml}$ のメスフラスコに $1.0 \times 10^{-3} \mathrm{M} \mathrm{Nb}(\mathrm{V})$ 液 0.5 $\mathrm{ml}, 1.0 \%$ Tween 40 液 $1.0 \mathrm{ml}$, Walpole 緩衝液 $(\mathrm{pH} 4.3)$ $2.5 \mathrm{ml}$ 及び $2.0 \times 10^{-3} \mathrm{M}$ BPR 液 $0.6 \mathrm{ml}$ を加え, 次いで ほほ2〜32 $\mu \mathrm{g}$ までの CPM を加え水で $10 \mathrm{ml}$ とする. 別に同様に処理して得た $\mathrm{BPR}-\mathrm{Nb}(\mathrm{V})$ 液（B 液）ととも $に 30{ }^{\circ} \mathrm{C}$ で 20 分間静置後 BPR- $\mathrm{Nb}(\mathrm{V})-\mathrm{CPM}$ 液 (A 液) の $635 \mathrm{~nm}$ での吸光度を $\mathrm{B}$ 液を対照に測定し，あらかじ め作成して得た検量線より CPM 量を求める.

\section{3 結果と考察}

\section{$3 \cdot 1$ 色素及び金属イオンの選定}

まず，使用する色素及び金属イオンの組み合わせの予 備的検討として, 色素に BPR, ピロガロールレッド (PR)，ピロカテコールバイオレット (PV)，クロムアズ ロール B $(\mathrm{CAB})$, キシレノールオレンジ $(\mathrm{XO})$, フェ ニルフルオロン $(\mathrm{PF}), \mathrm{QP}$ など, また金属イオンに $\mathrm{Nb}(\mathrm{V})$, タンタル(V) $\{\mathrm{Ta}(\mathrm{V})\}$, スズ(IV) $\{\mathrm{Sn}(\mathrm{IV})\}$, ジルコニウム(IV) $\{\mathrm{Zr}(\mathrm{IV})\} ，$ チタン (IV) $\{\mathrm{Ti}(\mathrm{IV})\} ， モ$ リブデン $(\mathrm{VI}) \quad \mathrm{Mo}(\mathrm{VI})\}$ などを選びその発色反応を比 較した，その結果，色素及び金属イオンの鋭敏性の順序 はそれぞれ $\mathrm{BPR} \gg \mathrm{CAB}>\mathrm{PV}>\mathrm{QP}>\mathrm{PR}>\mathrm{PF}$ 及び $\mathrm{Nb}(\mathrm{V})>\mathrm{Sn}(\mathrm{IV})>\mathrm{Zr}(\mathrm{IV})>\mathrm{Ti}(\mathrm{IV})>\mathrm{Mo}(\mathrm{VI})>\mathrm{Ta}(\mathrm{V})$ で あった。したがって，本 CPM の定量法に際しては，市 販色素の $\mathrm{BPR}$ と金属イオンの $\mathrm{Nb}(\mathrm{V})$ を用いて基礎的定 量条件の設定を行った.

\section{$3 \cdot 2$ 吸収スペクトル}

非イオン性界面活性剤 Tween 40 共存下, pH 4.3 付近

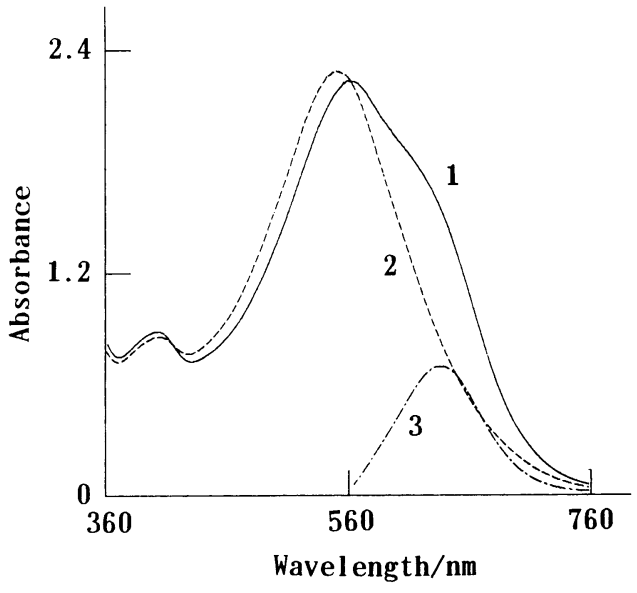

Fig. 1 Absorption spectra obtained under the standard procedure $(2 \cdot 2)$

CPM taken: $8.0 \times 10^{-6} \mathrm{M}$; Curve 1: $\mathrm{CPM}-\mathrm{Nb}(\mathrm{V})$ BPR against water; Curve 2: $\mathrm{Nb}(\mathrm{V})-\mathrm{BPR}$ against water; Curve 3: curve 1 minus curve 2

で $\mathrm{BPR}-\mathrm{Nb}(\mathrm{V})-\mathrm{CPM}$ (A 液) と $\mathrm{BPR}-\mathrm{Nb}(\mathrm{V})$ 液（B夜 $)$ の間には明りょうな発色差が認められ，635 nm 付近の 吸光度変化が CPM 濃度に比例するので, 以下の定量操 作に $635 \mathrm{~nm}$ を用いることにした。

\section{$3 \cdot 3 \mathrm{pH}$ の影響}

Walpole の $0.2 \mathrm{M}$ 酢酸-酢酸ナトリウム緩衝液を全量 $10 \mathrm{ml}$ に対し 2〜 $4 \mathrm{ml}$ 加えて, 最終的に $\mathrm{pH} \mathrm{3.9 \sim 4.7}$ に液性調整するとき，ほぼ一定で最大の吸光度を示し た。

\section{$3 \cdot 4$ 界面活性剤の影響}

生成する発色錯体の水溶性化, 安定化及び定量感度の 上昇を目的として非イオン性 [Tween 40，Tween 80, Tween 20, Triton N-101, Triton X-405, Triton X-305, Triton X-100, Brij 35, Brij 58，ポリビニルアルコール $(n=500) ，$ ポリビニルピロリドン（K-30)，アラビアゴ ム末，陽イオン性 [塩化ステアリルトリメチルアンモ ニウム，塩化セチルピリジニウム，陰イオン性［ラウ ロイルザルコシンナトリウム，硫酸ドデシルナトリウ 厶］あるいは両性［Swanol 301］界面活性剂の併用を検 討した。その結果，陽イオン性，陰イオン性及び両性界 面活性剤の共存は本発色反応を著しく妨害した。非イオ ン界面活性骿としては，Tween 系が最も高感度を与え るが，そのうち $1.0 \%$ Tween 40 液を全量 $10 \mathrm{ml}$ に対し 
Table 1 The sensitivities and reproducibilities of the proposed method with drugs studied

\begin{tabular}{lcc}
\hline Drug & $\varepsilon^{\mathrm{a})}\left(\times 10^{4}\right)$ & $\mathrm{RSD}^{\mathrm{b})}, \%$ \\
\hline CPM & 8.0 & 0.83 \\
Diphenhydramine & 0.85 & 1.25 \\
Astemizole & 0.80 & 1.34 \\
Ketotifen & 0.37 & 2.07 \\
Histamine & 6.0 & 0.85 \\
Papaverine & 4.0 & 0.92 \\
\hline
\end{tabular}

a): molar absorptivity $\left(1 \mathrm{~mol}^{-1} \mathrm{~cm}^{-1}\right)$

b): relative standard deviation $(n=8)$

$0.5 \sim 2 \mathrm{ml}$ 使用するとき, $\mathrm{A}$ 液は安定で再現性ある吸光 度を示した。

\section{$3 \cdot 5 \mathrm{Nb}(\mathrm{V})$ 及び BPR 量の影響}

$\mathrm{CPM}\left(2.0 \times 10^{-6} \mathrm{M}, 4.0 \times 10^{-6} \mathrm{M}\right)$ 及び $5.0 \times 10^{-5}$ $\mathrm{M} \mathrm{Nb}(\mathrm{V})$ に対し，BPR 液を $\mathrm{Nb}(\mathrm{V})$ 液のほほ 2 倍以上用 いるとき，一定の吸光度を示した。したがって，B 液の 吸光度及び $\mathrm{CPM}$ の定量限界を考慮して, $5.0 \times 10^{-5} \mathrm{M}$ $\mathrm{Nb}(\mathrm{V})$ 及び $1.2 \times 10^{-4} \mathrm{M}$ BPR を定量操作に用いること にした。

\section{$3 \cdot 6$ 発色体の安定性}

発色体の安定性を室温で検討したところ，15〜 60 分 間静置するとき，吸光度はほぼ定値を示すが，より感 度の上昇と再現性の向上を目的として, 加温操作を検討 した．加温温度として $20,25,30,35,40^{\circ} \mathrm{C}$, 加温時 間として $10 〜 60$ 分間静置後の吸光度を比較した結果, $30^{\circ} \mathrm{C}$ で 20 分間静置後の吸光度を測定するとき, 感度, 再現性とも最適であった．また，試薬添加順序の検討を 行ったところ, $\mathrm{Nb}(\mathrm{V}) \rightarrow$ 界面活性剂 $\rightarrow$ 緩衝液 $\rightarrow \mathrm{BPR} \rightarrow$ CPM の順に添加するとき, 最も高い吸光度が得られた。

\section{$3 \cdot 7$ 検量線の作成}

$2 \cdot 2$ の定量操作に従って CPM の検量線を作成したと ころ, 2 32 $\mu \mathrm{g}$ の CPM 濃度において良好な直線（ $Y=$ $0.020 X-0.001, r=0.998)$ を得た。なお，定量下限は $10 \sigma$ ( $\sigma$ は空試験試料の測定値の標準偏差) に相当する CPM 濃度とした. CPM 及びその他二, 三の抗ヒスタミ ン薬関連化合物と見掛けのモル吸光係数 $\left(\varepsilon, 1 \mathrm{~mol}^{-1}\right.$ $\mathrm{cm}^{-1}$ ) 及び相対標準偏差（RSD）を Table 1 に示す. 本操作に打ける $\mathrm{CPM}$ 定量時の感度は $\mathrm{QP}-\mathrm{Ti}(\mathrm{IV})-\mathrm{F}^{-}$ 法5)のほほ 1.2 倍以上, ジンコン法6)の 2.4 倍以上を示し， 分析精度も向上することを認めた。 なお，定量感度はへ
Table 2 Effect of foreign substances on the recovery of CPM

\begin{tabular}{lcc}
\hline Substance & Molar ratio $^{\dagger}$ & Recovery, \% \\
\hline None & - & 100.0 \\
$\mathrm{Fe}(\mathrm{III})$, alum & 0.4 & 103.3 \\
$\mathrm{Cu}(\mathrm{II})$, sulfate & 0.4 & 92.8 \\
$\mathrm{NaCl}$ & 100 & 100.0 \\
$\mathrm{KNO}_{3}$ & 100 & 100.0 \\
$\mathrm{KH}_{2} \mathrm{PO}_{4}$ & 20 & 98.5 \\
$\mathrm{Glucose}_{\text {Glycine }}$ & 100 & 100.0 \\
Taurine & 100 & 100.0 \\
Caffeine & 100 & 100.0 \\
Citric acid & 100 & 100.0 \\
Ascorbic acid & 20 & 100.0 \\
Thiamine & 50 & 100.0 \\
Pyridoxine & 5 & 100.0 \\
Norephedrine & 20 & 100.0 \\
Lysozyme & 40 & 102.5 \\
Methylcellulose & $(50.5 \mu \mathrm{g})$ & 101.6 \\
\hline
\end{tabular}

CPM taken: $5.0 \times 10^{-6} \mathrm{M} ;{ }^{\dagger}:$ substance $/ \mathrm{CPM}$

Table 3 Determination of CPM in pharmaceutical preparations

\begin{tabular}{ccccc}
\hline & \multicolumn{3}{c}{ Content/mg } & Recovery, \\
Sample & $\begin{array}{c}\text { Nominal } \\
\text { amount }\end{array}$ & $\begin{array}{l}\text { Present } \\
\text { method }\end{array}$ & $\begin{array}{l}\text { Other } \\
\text { method }^{\text {a) }}\end{array}$ & \\
\hline A & 0.300 & 0.307 & 0.310 & 98.3 \\
B & 0.100 & 0.108 & 1.098 & 97.7 \\
C & 0.300 & 0.287 & 0.169 & 100.5 \\
D & 3.200 & 3.330 & - $^{\text {b) }}$ & 103.9 \\
E & 0.400 & 0.384 & - $^{\text {b) }}$ & 99.5 \\
F & 2.000 & 2.126 & b $^{\text {b) }}$ & 102.8 \\
\hline
\end{tabular}

Sample A: eye drop (in $1 \mathrm{ml}$ ), also contained $\varepsilon$ aminocaproic acid $(10 \mathrm{mg})$, dipotassium glycyrrhizinate $(1.7 \mathrm{mg})$, phenylephrine. HCI $(1.0 \mathrm{mg})$; Sample B: eye drop (in $1 \mathrm{ml}$ ), also contained tocopherol acetate $(0.15 \mathrm{mg})$, neostigmine $(0.05 \mathrm{mg})$, aminoethylsulfonic acid $(0.1 \mathrm{mg})$; Sample C: syrup (in $1 \mathrm{ml}$ ), also contained codeine phosphate (1.5 $\mathrm{mg})$, methylephedrine. HCI $(2.0 \mathrm{mg})$, Senega extract (1.2 $\mathrm{mg}$ ); Sample D: capsule (in 1 capsule); also contained phenylpropanolamine. HCI (40.0 mg), Belladonna alkaloid (0.2 mg); Sample E: syrup (in 1 $\mathrm{ml}$ ), also contained dihydrocodeine phosphate (1.0 $\mathrm{mg})$, guaifenesin $(5.7 \mathrm{mg})$, caffeine $(2.1 \mathrm{mg})$; Sample F: lotion (in $1 \mathrm{ml}$ ); also contained ephedrine. HCI $(1.5 \mathrm{mg})$, dibucaine. HCI $(1.0 \mathrm{mg})$, cetylpyridinium chloride $(1.0 \mathrm{mg})$.

a) QP-Ti(IV) - $\mathrm{F}^{-}$method, b) undetermined 
テロ環窒素原子を持つ薬物が相対的に高いことが示唆さ れるが,より詳細な検討を行う必要がある.

\section{$3 \cdot 8$ 共存物質の影響}

本定量法における共存物質の影響を CPM $\left(5.0 \times 10^{-6}\right.$ M）を用いて検討したところ, CPMの 5 倍モル量以内 のチアミン, 20 倍モル量以内のクエン酸, ピリドキシ ン, 50 倍モル量以内のアスコルビン酸, ノルエフェド リン, 多量の塩化ナトリウム, グルコース, グリシン, タウリン，カフェインなどの共存は妨害しなかった。一 方, 金属イオンの鉄 (III) イオン, 銅 (II) イオンなどの 共存はそれぞれ正, 負の誤差を, また少量のリゾチーム は正の誤差を与えた。結果を Table 2 に要約した.

\section{$3 \cdot 9$ 錯体の組成}

本発色体の組成を連続変化法, モル比法で検討したと ころ, $\mathrm{Nb}: \mathrm{BPR}: \mathrm{CPM}=1: 2: 1$ の結果が得られた. したがって, 本発色反応で生成する錯体は, $\mathrm{Nb}(\mathrm{BPR})_{2}$ $(\mathrm{CPM})$ の三元錯体と推定されるが, 本質的に本発色体 がどのような錯体（イオン会合錯体, 混合配位子錯体, など）なのかといった詳細な検討が今後必要である.

\section{$3 \cdot 10$ 製剤中の CPM 分析}

本定量法を市販製剂 (点眼剂, シロップ剂, カプセル 剂，ローション剤）中の CPMの分析に応用したところ， Table 3 に見られるように分析值, 回収率とも良好で, 同時に併行実験した $\mathrm{QP}-\mathrm{Ti}(\mathrm{IV})-\mathrm{F}^{-}$法 $^{5)}$ に比べ良好な結 果を示した. したがって本法は，複合製剂中の CPMの 実用分析法として十分適用できることを認めた.

$\left(\begin{array}{l}1998 \text { 年 } 4 \text { 月, 日本薬学会 } \\ \text { 第 } 118 \text { 年会において発表 }\end{array}\right)$

\section{文献}

1) Y. Fujita, I. Mori, S. Kitano: Chem. Pharm. Bull., 31, 1289 (1983).

2) Y. Fujita, I. Mori, K. Fujita, Y. Nakahashi, T. Tanaka: Chem. Pharm. Bull., 35, 5004 (1987).

3) Y. Fujita, I. Mori, M. Toyoda: Anal. Sci., 6, 807 (1990).

4) Y. Fujita, I. Mori, M. Toyoda: Anal. Sci., 8, 313 (1992).

5) Y. Fujita, I. Mori, S. Kitano: Bunseki Kagaku, 32, E327 (1983).

6) 服部忠雄, 熟尾幸夫, 井上正秀: 分析化学 (Bunseki Kagaku), 27, 707 (1978).

\section{要旨}

ピロガロールレッド及びニオブ $(\mathrm{V})$ との三元錯体生成反応を用いるマレイン酸クロルフェニラミンの 簡便, 迅速で高感度な吸光光度定量法を開発した. $635 \mathrm{~nm}$ での吸光度を測定する定量操作における相対 標準偏差は $0.83 \% （ 19.6 \mu \mathrm{g}, n=8)$ であった. マレイン酸クロルフェニラミンと配合されやすい薬物

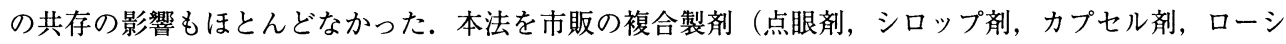
ヨン剤）中のマレイン酸クロルフェニラミン分析に応用したところ，回収率はほほ $98 \sim 104 \%$ を示し， 分析值も良好であり, 実用分析法として十分利用できることを認めた. 